Фармацевтичний менеджмент, маркетинг та логістика

Pharmaceutical management, marketing and logistics

Рекомендована д. фрармац. наук, проф. К. Л. Косяченком

УДК 615.1:061.2

DOI 10.11603/2312-0967.2017.1.7529

\title{
ВИЗНАЧЕННЯ ПРІОРИТЕТНИХ НАПРЯМКІВ УДОСКОНАЛЕННЯ ДЕРЖАВНОГО ТА СУСПІЛЬНОГО РЕГУЛЮВАННЯ У ФАРМАЦІЇ
}

\author{
(C) І. В. Сушарина ${ }^{1}$, А. С. Немченко, В. М. Хоменко ${ }^{1}$ \\ ${ }^{1}$ Донецький національний медичний університет, краматорськ \\ Національний фрармацевтичний університет, Харків \\ asnemchenko@ukr.net
}

\begin{abstract}
Мета роботи. Визначення пріоритетних напрямків удосконалення державного та суспільного регулювання у орармації.

Матеріали і методи. Були використані системний підхід, аналітичний, статистичний, грасічний та метод анкетного опитування респондентів.

Результати й обговорення. За результатами проведеного анкетного опитування фахівців були визначені проблеми та встановлені найбільш важливі пріоритети щодо реформування системи державного й суспільного регулювання у фрармації. Одержані результати опитування фрахівців за 2011 - 2012 рр. та 2015-2016 рр. було порівняно 3 даними дослідження 2007 р. Було реалізовано актуальне завдання щодо оцінки проблем розвитку вітчизняної фрармації та визначення пріоритетних напрямків удосконалення державного та суспільного регулювання у вітчизняній фрармації за останні десять років.

Висновки. Встановлено, що найбільш ефективними засобами державного регулювання респонденти вважають економічні (більше 71 \% спеціалістів фрармації та 80 \% керівників відповідно). Слід зазначити, що за останні десять років у даному випадку змінились пріоритети, у дослідженні 2007 р. більше 80,0 \% опитаних (перше місце) віддавали перевагу використанню засобам правового спрямування.

Встановлено, що більше 60 \% керівників та спеціалістів вважають можливим повну передачу громадським організаціям фрункції атестації фрармацевтичних кадрів. Понад 35 \% фрахівців фрармації вважають можливою передачу громадським організаціям й таких фрункцій, як ліцензування діяльності, пов'язаної 3 роздрібною реалізацією ліків, а також акредитація установ, закладів і підприємств фрармацевтичної галузі (більш ніж 17 \%).
\end{abstract}

Ключові слова: фрармація; державне та суспільне регулювання; удосконалення; пріоритетні напрямки; анкетне опитування; спеціалісти фрармації.

Вступ. 3 часів переходу України до ринкових відносин виникла низка проблем щодо забезпечення соціальних гарантій держави з доступності медичної та фрармацевтичної допомоги хворим. У сучасних умовах це досягається шляхом застосування різних механізмів державного регулювання у фармації [1-4].

Водночас світові тенденції вказують, що у розвинутих країнах поряд 3 державним, використовується й суспільне регулювання певних галузей (у т. ч. й системі охорони здоров'я та фрармації) відповідними фраховими громадськими організаціями, яким держава передає певні регуляторні фуннції $[8,9]$. Для фрармації у більшості країн характерним $є$ делегування державою фрармацевтичним громадським організаціям таких регуляторних фрункцій, як атестація кадрів, акредитація установ, закладів та підприємств галузі й ліцензування роздрібної реалізації лікарських засобів $[1,5]$.

В Україні, враховуючи обраний євроінтеграційний шлях на демократизацію соціально-економічних процесів, постає питання реформування державного та суспільного регулювання як в економіці взагалі, так і в фрармації зокрема. Тому перед нами постало актуальне завдання визначення пріоритетних напрямків удосконалення державного та суспільного регулювання у вітчизняній фрармації.

Аналіз останніх досліджень та публікацій фрахових видань дозволив стверджувати, що проблемі удосконалення державного та суспільного регулювання приділяється досить обмежена увага науковців та практиків [1-7]. Тому актуальним вбачається проведення досліджень із реформування державного та суспільного регулювання з використанням анкетного опитування фрармацевтичних фрахівців.

3 огляду на актуальність питання, метою дослідження стало визначення проблем регулювання у фрармації, а також пріоритетних напрямків удосконалення державного та суспільного регулювання в галузі. Як методи дослідження були використані системний підхід, аналітичний, статистичний, графрічний та метод анкетного опитування респондентів.

Результати й обговорення. Донецьким національним медичним університетом спільно 3 Націо-

ISSN 2312-0967. Фармацевтичний часопис. 2017. № 1 
нальним фрармацевтичним університетом у 2011 2012 рр. (далі - І дослідження) та в 2015-2016 рр. (далі - II дослідження) було проведене всеукраїнське анкетне опитування спеціалістів фрармації та керівників, зокрема державних службовців, з метою оцінки їх ставлення до проблем державного управління фармацевтичною галуззю України та удосконалення державного управління фрармацевтичною галуззю за можливої участі громадських фрармацевтичних організацій у суспільному регулюванні у фрармації. Одержані результати експертного дослідження I та II в подальшому було порівняно 3 даними дослідження В. М. Хоменко (2007р.) [1-3]. Таким чином, було реалізовано завдання щодо оцінки проблем розвитку вітчизняної фрармації та визначення пріоритетних напрямків удосконалення державного та суспільного регулювання у вітчизняній фрармації за останні десять років 2007-2016 рр.

При розробці анкет був використаний системний підхід відносно їх структури та конкретних питань, яких у кожній з анкет було по 14. У структурі анкети було виділено три розділи:

1. Загальні дані про респондентів (область, місце роботи, стать, вік, стаж).

2. Визначення основних проблем та пріоритетних напрямків удосконалення державного управління фрармацією.

3. Оцінка ефрективності діяльності та можливостей участі громадських фрармацевтичних організацій у регуляторній діяльності в галузі.

Питання другого розділу обох анкет однакові, що дозволяє порівняти відповіді різних груп респондентів. Третій розділ включає специфічні питання для кожної групи респондентів, а саме: для керівників, зокрема державних службовців, щодо оцінки ефективності діяльності фрармацевтичних асоціацій, з якими вони співпрацюють; для спеціалістів фрармації щодо оцінки діяльності громадських організацій в цілому та обласної асоціації, членами якої вони є.

Проведення відбору респондентів здійснювалося 3 допомогою цілеспрямованого відбору експертів 3 урахуванням таких основних чинників: включення до опитування фрахівців із більшості регіонів (областей) України та сорер діяльності за двома групами (керівники та спеціалісти фрармації); фрормування статистично достовірної вибірки, а саме 10-15 \% кількість експертів від загальної чисельності кожної з груп; високий освітньо-кваліфікаційний рівень; наявність необхідного професійного стажу роботи.

В анкетному опитуванні прийняло участь: 56 (I) та 50 (II) керівників, а також 621 (I) й 539 (II) спеціалістів фрармації з 21 (I) та 19 (II) регіонів України. Усі респонденти за двома дослідженнями мають вищу освіту, з них 14 (I) та 11 (II) мають науковий ступінь кандидата і 2 - доктора наук (I та II).

3 метою об'єктивності визначення пріоритетних напрямків удосконалення регулювання у вітчизняній фармації на першому етапі дослідження нами була проведена оцінка характерних проблем системи управління фрармацією, в якій зацікавлені як керівники, так і спеціалісти практичної фармації. За результатами опитування встановлено, що найбільшою проблемою державного управління $є$ недосконалість законодавчої та нормативно-правової бази. На це вказало більшість як керівників 82,14 і 74 \% та 69,73 й 64,91 \% спеціалістів в I і II дослідженнях (рис. 1).

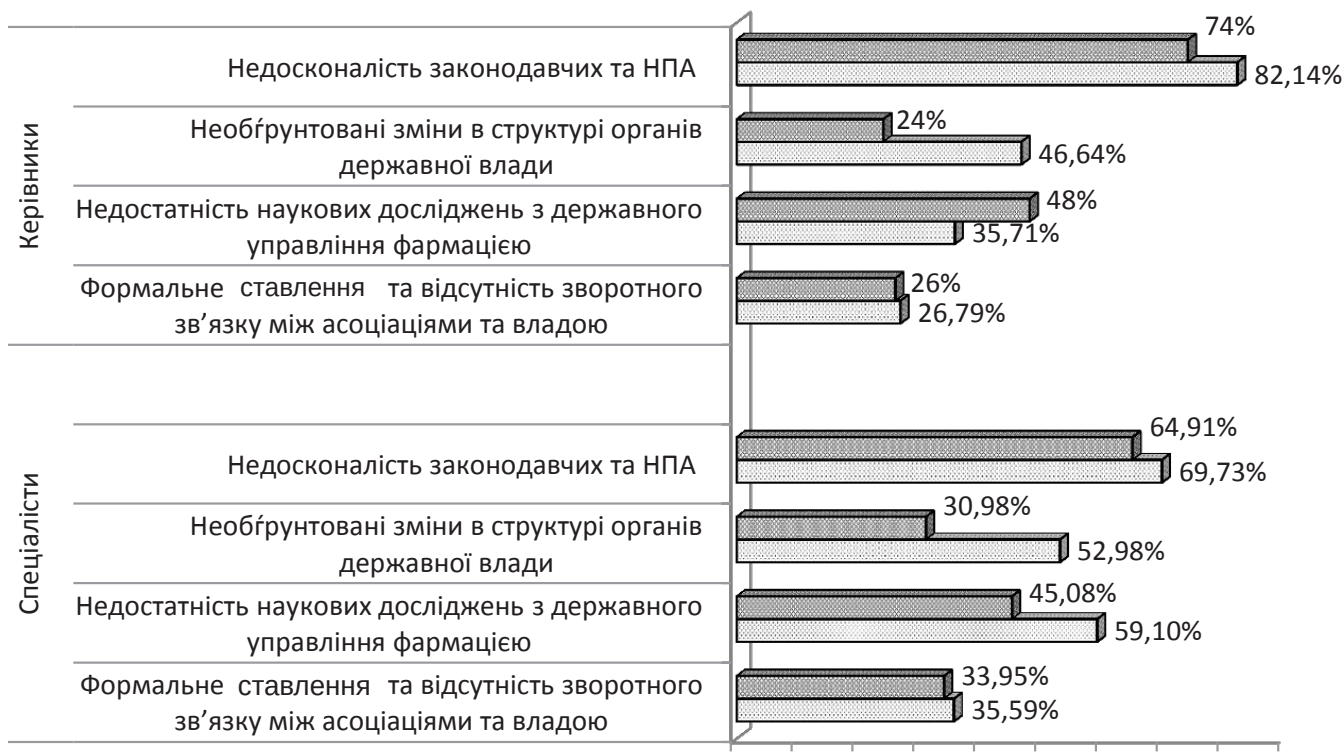

0\% 10\% 20\% 30\% 40\% 50\% 60\% 70\% 80\% 90\%

2015-2016 pp. 용 2011-2012 pp.

Рис. 1. Оцінки фрахівців щодо основних проблем державного управління вітчизняною фрармацією.

ISSN 2312-0967. Pharmaceutical review. 2017. № 1 
Фармацевтичний менеджмент, маркетинг та логістика Pharmaceutical management, marketing and logistics

Відповіді на інші питання фахівців в обох дослідженнях були неоднозначні. Так, якщо в І дослідженні друге місце як керівники, так і спеціалісти відводили проблемі необґрунтованості змін у структурі органів державного управління срармацією (46,64 та 52,98 \%), то в II дослідженні фрахівці поставили її на четверте місце (24,0 та 30,98 \%), що пояснюється значним скороченням фрункцій управління із-за введення мораторію на перевірки суб'єктів господарювання. У свою чергу, в II дослідженні керівники та спеціалісти (48,0 та 45,08 \%) віддали друге місце такій відповіді, як недостатність наукових досліджень щодо державного управління фрармацією. На фрормальне ставлення до думки професійних асоціацій вказали 26,79 та $26 \%$ керівників та 35,59 й 33,95 \% спеціалістів відповідно, тобто спеціалісти більше переймаються цією проблемою, ніж керівники.

У дослідженні В. М. Хоменко були виділені аналогічні проблеми. Однак слід виділити позитивну тенденцію за десятирічний період: число респондентів, які вибрали відповідь стосовно фрормального ставлення до думки професійних асоціацій суттєво зменшилась.

Розробка сучасних принципів державного та суспільного регулювання у вітчизняній фармації вимагає цілісного та комплексного підходу. У зв'язку з цим нами пропонувалося респондентам дати відповіді на запитання щодо характеру здійснення ефективних трансорормацій з урахуванням ринкових та соціальних складових. Отримані результати представлені на рисунку 2.

Поєднання державного регулювання та соціальних і ринкових змін віднесено фахівцями до найбільш пріоритетних (рис. 2). На це вказала більшість керівників 56 та 35,71 \% в I і II дослідженнях, тоді як спеціалісти відвели йому друге і третє місце - 30,92 й 23,01 \% відповідно. На друге місце керівники і спеціалісти в дослідженні 2015-2016 рр. поставили пріоритет щодо посилення впливу асоціацій на процеси регулювання галузі, що $є$ повністю закономірним. У свою чергу, спеціалісти віддали перше місце такій відповіді, як створення конкурентних умов на засадах фрармацевтичної етики в ринковому середовищі - 34,46 та 50,83 \% відповідно. Найменш популярною $€$ жорстка система регулювання, перевагу якій віддають $20,0 \%$ і менше респондентів.

Порівняння з результатами дослідження В. М. Хоменко свідчить, що більшість визначених пріоритетів залишилася, змінився їх вплив. Наприклад, оцінки респондентів за пріоритетами - створення конкурентних умов на засадах фрармацевтичної етики, а також посилення впливу асоціацій на регулювання у фармації, за десятирічний період аналізу збільшились більш ніж на $10 \%$.

Механізм державного регулювання розглядається як сукупність різних засобів (економічних, правових

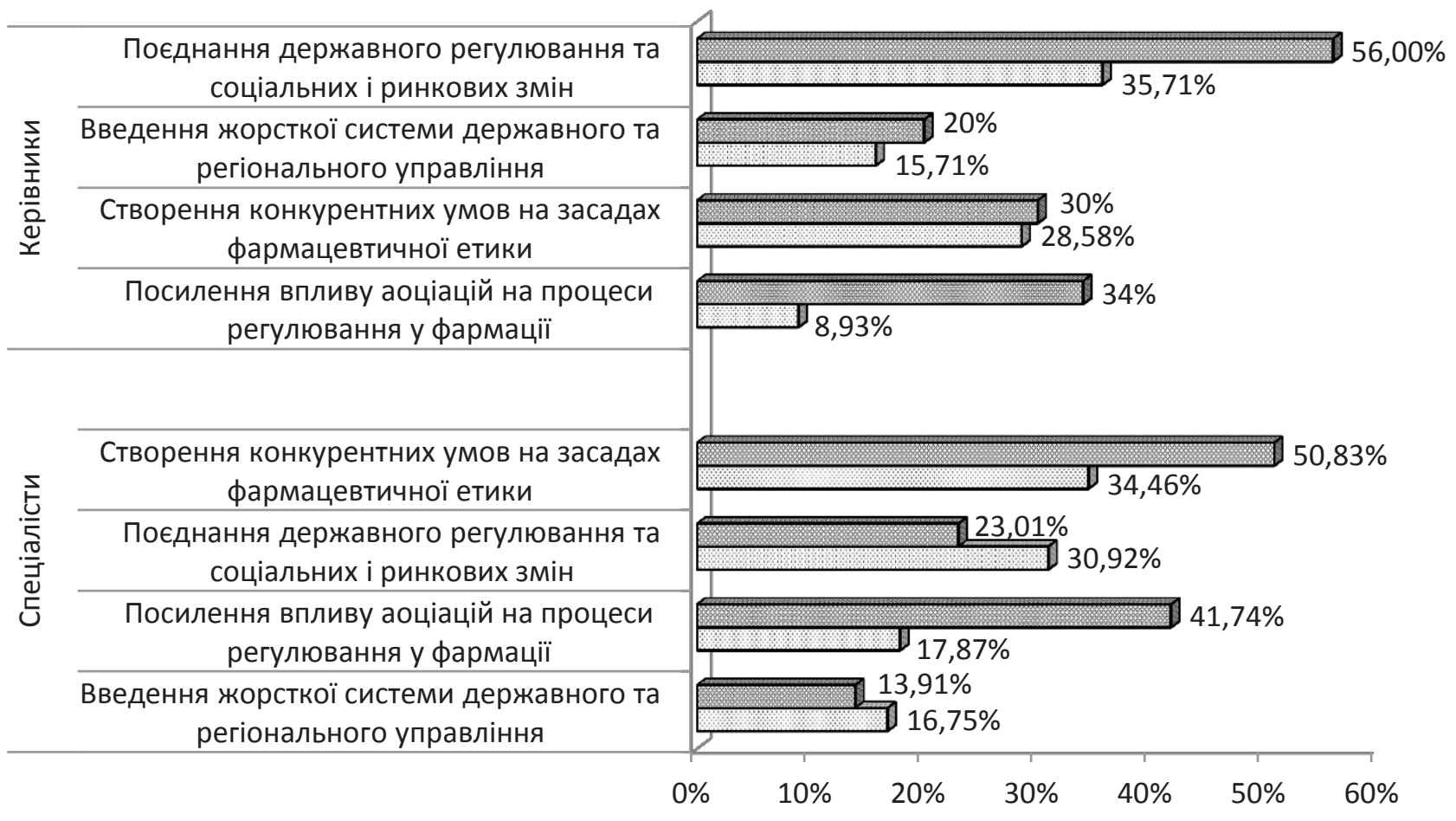

잉 2015-2016 pp. 2011-2012 pp.

Рис. 2. Оцінки респондентів щодо пріоритетних напрямків удосконалення державного та суспільного регулювання у вітчизняній фармації.

ISSN 2312-0967. Фармацевтичний часопис. 2017. № 1 
та ін.) цілеспрямованого комплексного впливу 3 метою посилення потенціалу фрармацевтичної галузі. На рисунку 3. представлено розподіл за значимістю, на думку респондентів, найбільш ефективних засобів державного регулювання у фрармації.

Як видно 3 даних рисунка 3 перше місце за ефективністю засобів державного регулювання респонденти віддали економічним (80,36 та 76 \% керівників та 73,27 і 71,06 \% спеціалістів фрармації відповідно). Друге місце респонденти віддали правовим засобам державного регулювання - 64,29 і 68 \% керівники та спеціалісти 67,63 й 64,94 \%. Також до ефективних методів респонденти віднесли соціальні засоби (більш ніж 42 \% опитаних із кожної категорії). Слід зазначити, що за останні десять років в даному випадку змінились пріоритети, у дослідженні В. М. Хоменко більше 80,0 \% опитаних (перше місце) віддавало перевагу використанню засобам правового спрямування.

Зміна пріоритетів у засобах державного регулювання в фрармації за 2007-2016 рр. поставила завдання більш поглибленого дослідження цього питання. Результати оцінки ефективності основних методів державного регулювання у фрармації наведено на рисунку 4. Найбільш пріоритетним за оцінками як керівників, так і спеціалістів в обох дослідженнях визначено правовий метод - ліцензування оптової та роздрібної реалізації лікарських засобів (Л3). Однак оцінки мають тенденції до зниження (більш ніж 11 \%): 91,07 і 82 \% керівники та 74,72 і 71,06 \% спеціалісти, що пояснюється підвищенням впливу перш за все соціально-економічних методів державного регулювання у фрармації. На другому місці знаходиться економічний метод - контроль цін на основні Л3, при цьому теж має місце зниження оцінок: 82,14 і 66 \% керівники та спеціалісти 71,82 і 66,98 \%.

Соціально-економічний метод компенсації (реімбурсації) вартості Лз займає третє місці, правовий рецептурний відпуск знаходиться на четвертому, економічний - податкові пільги займає п'яте місце. До інших методів державного регулювання респондентами віднесено адміністративні методи 3 контролю якості ЛЗ.

Порівняння одержаних результатів анкетного опитування з дослідженнями В. М. Хоменко свідчить про суттєву трансорормацію методів державного регулювання у фрармації за останні десять років.

На заключному етапі дослідження нами було визначено, які фрункції державного регулювання, на думку респондентів, слід повністю передати фрармацевтичним громадським організаціям.

Результати опитування з цього важливого питання наведено на рисунку 5. Одержані за двома дослідженнями дані вказують, що 64,29 і 76 \% керівників та 60,71 й 71,06 \% спеціалістів (перше місце) вважають можливим повну передачу професійним громадським організаціям функцію атестації фрармацевтичних кадрів. Більш ніж 35 \% керівників та 40 \% спеціалістів фрармації вважають можливим передачу фрармацевтичним асоціаціям фрункцій ліцензування діяльності, пов'язаної з роздрібною реалізацією ліків, відносно акредитації установ, закладів і підприємств

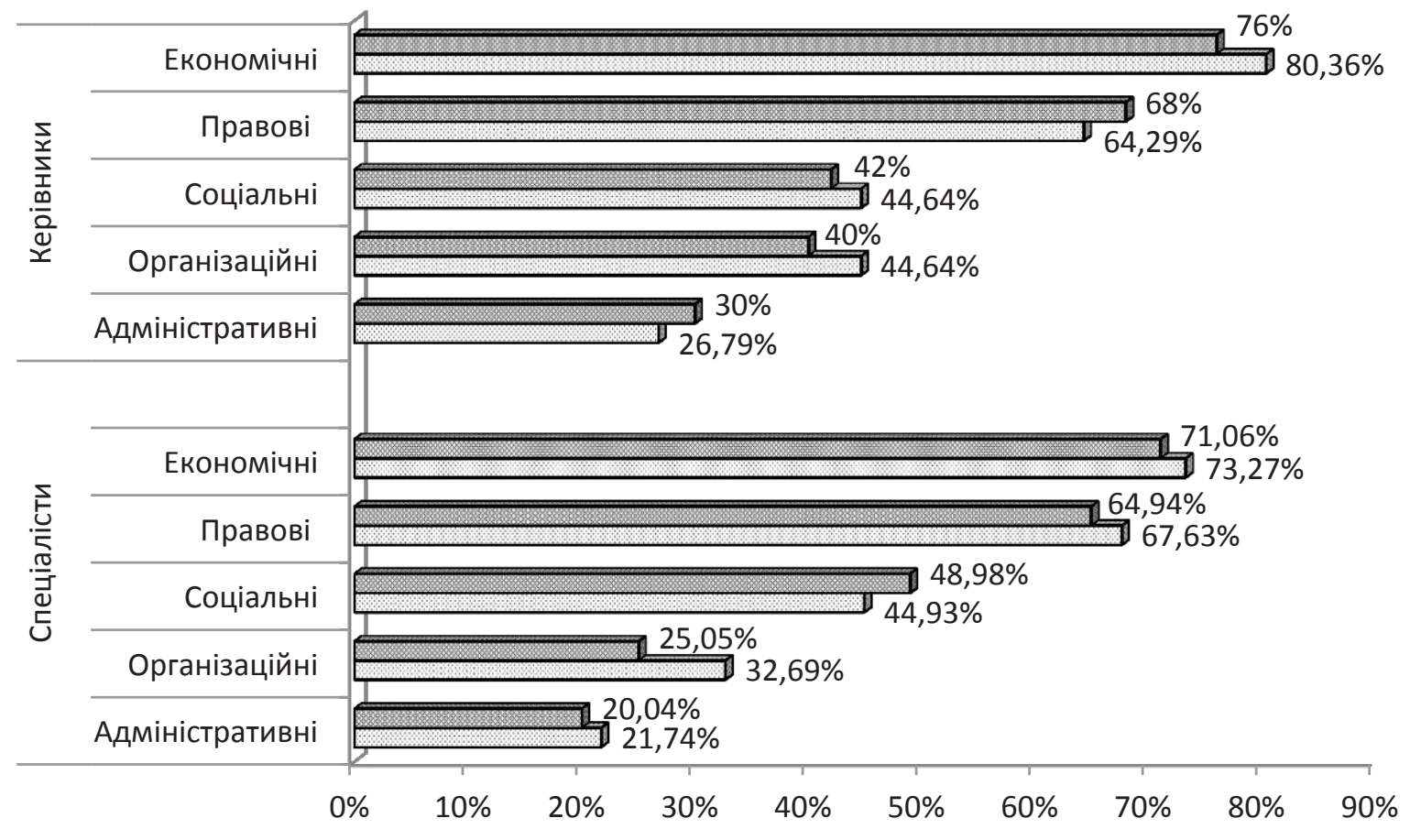

国 2015-2016 pp. @2011-2012 pp.

Рис. 3. Розподіл за значимістю найбільш ефективних засобів державного регулювання у фрармації.

ISSN 2312-0967. Pharmaceutical review. 2017. № 1 
Фармацевтичний менеджмент, маркетинг та логістика Pharmaceutical management, marketing and logistics

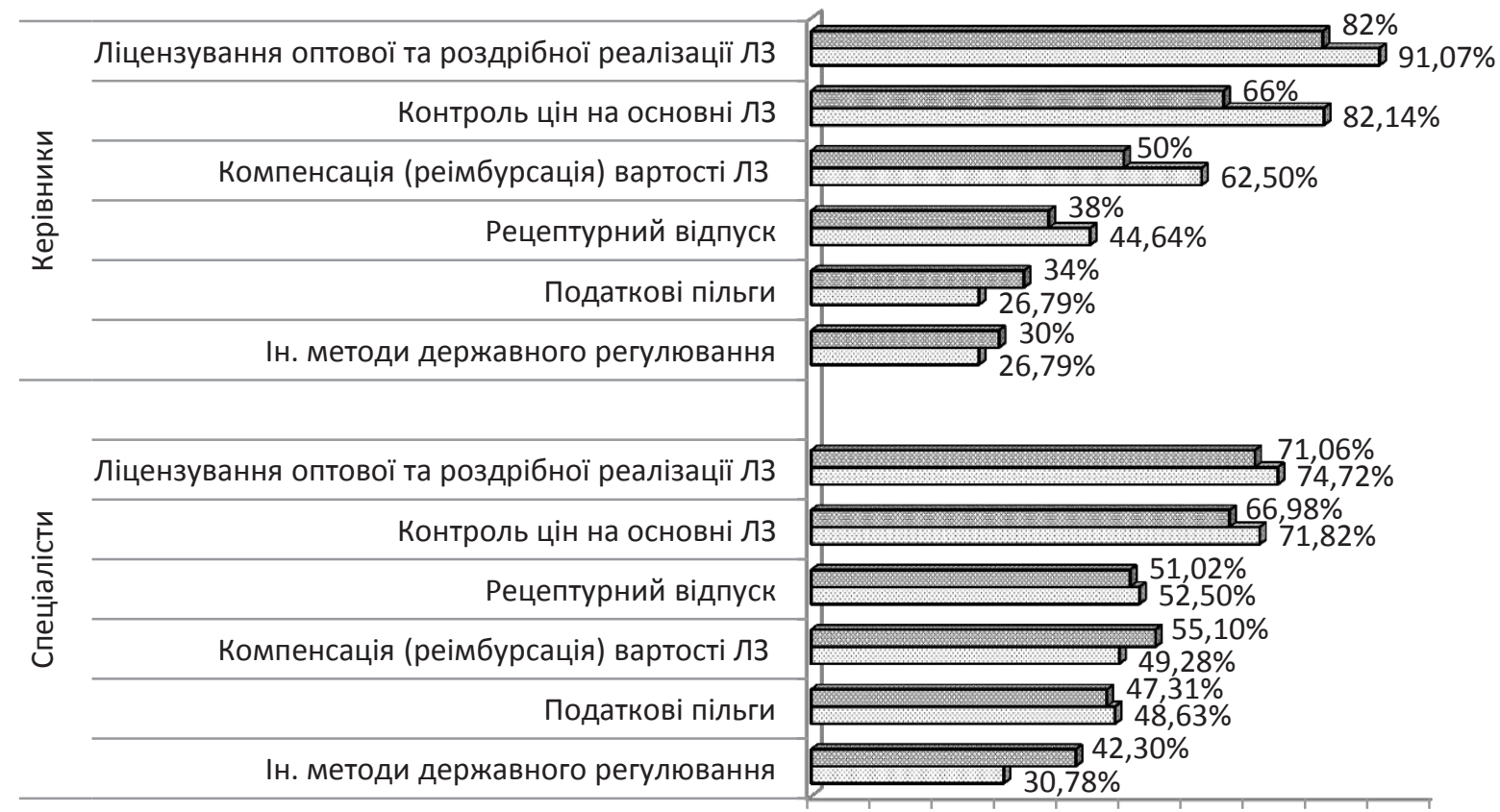

0\% 10\% 20\% 30\% 40\% 50\% 60\% 70\% 80\% 90\%100\%

图 2015-2016 pp. 2011-2012 pp.

Рис. 4. Результати оцінки респондентів щодо ефрективності методів державного регулювання у фармації.

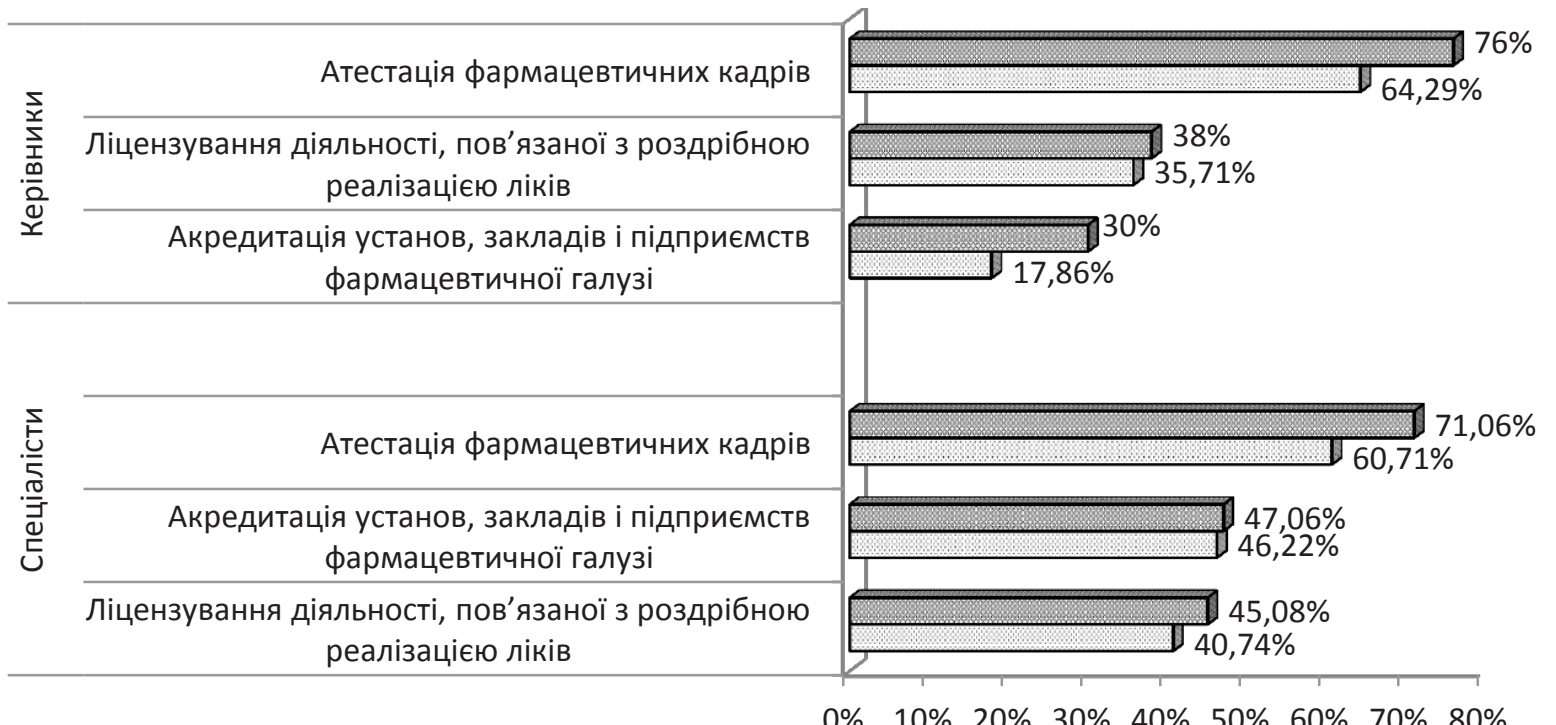

\section{图 2015-2016 pp. 2011-2012 pp.}

Рис. 5. Розподіл відповідей респондентів щодо функцій державного регулювання, які слід повністю передати фармацевтичним асоціаціям.

фрармацевтичної галузі - більш ніж 17 \% керівників та $46 \%$ спеціалістів.

Одержані оцінки анкетного опитування фрахівців були оброблені за допомогою пакета програм Statistica 10,0, в результаті встановлено достовірну узгодженість думок як керівників, так і спеціалістів фрармацевтів.
Таким чином, за результатами проведеного анкетного опитування фрахівців були визначені проблеми та встановлені найбільш важливі пріоритети щодо реформування системи державного й суспільного регулювання у фрармації.

Висновки. 1. 3 метою оцінки проблем та пріоритетів державного й суспільного регулювання у фрарма-

ISSN 2312-0967. Фармацевтичний часопис. 2017. № 1 
цевтичній галузі нами проведене всеукраїнське анкетне опитування керівників і спеціалістів фрармації за два періоди: I - 2011 - 2012 рр. та II - 2015 2016 рр. Для цього було сорормовано статистично достовірну вибірку респондентів із 21(I) та 19(II) регіонів та розроблена анкета, що складалась 3 трьох розділів. Одержані дані були порівняні 3 аналогічними дослідженнями 2007 р., встановлені тенденції за останні десять років.

2. За результатами опитування встановлено, що найбільшою проблемою державного управління $є$ недосконалість законодавчої та нормативно-правової бази. На це вказала більшість як керівників 82,14 і $74 \%$ та 69,73 й 64,91\% спеціалістів в обох дослідженнях. На фрормальне ставлення до думки професійних асоціацій вказали 26,79 і 26 \% керівників та 35,59 й 33,95 \% спеціалістів в обох дослідженнях, при цьому слід відмітити позитивну тенденцію за десятирічний період - число респондентів, які вибрали цю відповідь, зменшилась.

3. До найбільш пріоритетних фрахівці віднесли поєднання державного регулювання та соціальних і ринкових змін - 56 та 35,71 \% керівників у I і II дослідженнях відповідно. У свою чергу, спеціалісти віддали перше місце такому пріоритету, як створення кон- курентних умов на засадах фармацевтичної етики в ринковому середовищі - 34,46 та 50,83 \% відповідно. На друге місце керівники і спеціалісти в II дослідженні 2015-2016 рр. поставили пріоритет щодо посилення впливу асоціацій на процеси регулювання галузі. Порівняння з результатами дослідження 2007 р. свідчить, що більшість визначених пріоритетів залишилась, змінився їх вплив.

4. Найбільш ефективними засобами державного регулювання респонденти вважають економічні (більше 71\% спеціалістів фрармації та 80 \% керівників відповідно). Слід зазначити, що за останні десять років в даному випадку змінились пріоритети, у дослідженні 2007 р. більше 80,0 \% опитаних (перше місце) віддавало перевагу використанню засобам правового спрямування.

5. Встановлено, що більше $60 \%$ керівників та спеціалістів вважають можливим повну передачу громадським організаціям фрункції атестації фрармацевтичних кадрів. Понад 35 \% фрахівців фрармації вважають можливим передачу громадським організаціям й таких фрункцій, як ліцензування діяльності, пов'язаної з роздрібною реалізацією ліків, а також акредитація установ, закладів і підприємств фрармацевтичної галузі (більш ніж $17 \%$ ).

\title{
ОПРЕДЕЛЕНИЕ ПРИОРИТЕТНЫХ НАПРАВЛЕНИЙ СОВЕРШЕНСТВОВАНИЯ ГОСУДАРСТВЕННОГО И ОБЩЕСТВЕННОГО РЕГУЛИРОВАНИЯ В ФАРМАЦИИ
}

\author{
И. В. Сушарина ${ }^{1}$, А. С. Немченко, В. Н. Хоменко ${ }^{1}$ \\ ${ }^{1}$ Донецкий национальный медицинский университет, Краматорск \\ Национальный фрармацевтический университет, Харьков \\ asnemchenko@ukr.net
}

Цель работы. Определение приоритетных направлений совершенствования государственного и общественного регулирования в фрармации.

Материалы и методы. Были использованы системный подход, аналитический, статистический, грасрический и метод анкетного опроса респондентов.

Результаты и обсуждения. По результатам проведенного анкетного опроса специалистов были определены проблемы и установлены наиболее важные приоритеты реформирования системы государственного и общественного регулирования в фрармации. Полученные результаты опроса специалистов с 2011-2012 гг. и 20152016 гг. были сравнены с данными исследования за 2007 г. Было осуществлено актуальное задание по оценке проблем развития отечественной фрармации и определения приоритетных направлений совершенствования государственного и общественного регулирования в отечественной фрармации за последние десять лет.

Выводы. Установлено, что наиболее эффективными средствами государственного регулирования респонденты считают экономические (более 71 \% специалистов фрармации и 80 \% руководителей соответственно). Следует отметить, что за последние десять лет в данном случае изменились приоритеты, в исследовании 2007 р. больше 80,0 \% опрошенных (первое место) отдавало предпочтение использованию средствам правовой направленности. Установлено, что более 60 \% руководителей и специалистов считают возможным полную передачу общественным организациям фрункции аттестации фрармацевтических кадров. Более 35 \% специалистов фрармации считают возможным передачу общественным организациям и таких функций, как лицензирование деятельности, связанной с розничной реализацией лекарств, а также аккредитация учреждений, заведений и предприятий фрармацевтической отрасли (более $17 \%$ ).

Ключевые слова: фрармация; государственное и общественное регулирование; совершенствование; приоритетные направления; анкетный опрос; фрармацевтические работники.

ISSN 2312-0967. Pharmaceutical review. 2017. № 1 
Фармацевтичний менеджмент, маркетинг та логістика

Pharmaceutical management, marketing and logistics

\title{
IDENTIFYING OF THE PRIORITY AREAS FOR IMPROVING OF STATE AND PUBLIC REGULATION IN PHARMACY
}

\author{
I. V. Susharyna ${ }^{1}$, A. S. Nemchenko, V .M. Homenko ${ }^{1}$ \\ ${ }^{1}$ Donetsk National Medical University, Kramatorsk \\ National University of Pharmacy, Kharkiv \\ asnemchenko@ukr.net
}

The aim of the work. Determination of priority directions for improving state and public regulation in pharmacy.

Materials and Methods. We used a systematic approach, analytical, statistical, graphical and questionnaire survey method for respondents.

Results and Discussion. Based on the results of the questionnaire survey of specialists, problems were identified and the most important priorities for reforming the system of state and public regulation in pharmacy were established. The results of the survey of specialists from 2011-2012 and 2015-2016 were compared with the research data for 2007. An actual task was carried out to assess the problems of the development of domestic pharmacy and determine the priority directions for improving state and public regulation in domestic pharmacy over the past ten years.

Conclusions. It was found that respondents consider economic methods to be the most effective means of state regulation (more than $71 \%$ of pharmacy specialists and $80 \%$ of managers, respectively). It should be noted that in the last ten years priorities have changed in this case, in the 2007 study, more than $80.0 \%$ of respondents (the first place) preferred using legal means.

It is established that more than $60 \%$ of managers and specialists consider full transfer to the public organizations of the function of attesting pharmaceutical personnel. More than $35 \%$ of pharmacists consider it possible to transfer to public organizations and such functions as licensing of activities related to the retail sale of medicines, as well as the accreditation of institutions, institutions and enterprises by the pharmaceutical industry (more than $17 \%$ ).

Key words: pharmacy; government and public regulatory; improvement; priorities; questionnaire; pharmaceutical workers.

\section{Список літератури}

1. Хоменко В. М. Дослідження сучасних механізмів державного та суспільного регулювання у фрармації / В. М. Хоменко // Вісник фрармації. - 2007. - № 3 (51) - С. 38-42. 2. Немченко А. С. Визначення пріоритетів державної політики розвитку фрармацевтичної галузі на основі експертних оцінок / А. С. Немченко, В. М. Хоменко, І. К. Ярмола // Фармац. журн. - 2008. - № 2. - С. 3-8.

3. Немченко А. С. Проблеми розвитку фрармацевтичної галузі: експертна оцінка фрахівців / А. С. Немченко, В. М. Хоменко, І. К. Ярмола // Фармацевтичний часопис. - 2008. - № 2(6). - С. 11-13.

4. Актуальні питання регулювання галузі. Наради професійних фрармацевтичних об'єднань // Еженедельник Аптека. - 2010. - № 727(6). - С. 10.

5. Пашков В. Саморегулювання на фрармацевтичному рин- ку / В. Пашков // Еженедельник Аптека. - 2013.- № 41 (912). 6. Бочерикова $€$. Об'єднання професійних зусиль допоможе розвитку фрармації в Україні // Еженедельник Аптека. - 2016. - № 40 (1061).

7. Сушарина І. В. Науково-методичні підходи до оцінки ефективності діяльності громадських організацій у фрармації / І. В. Сушарина, А. С. Немченко, В.М.Хоменко // Управління, економіка та забезпечення якості в фрармації. - 2016. - № 3. - C. 6-74.

8. Oliynyk, D. Modern methods of evaluating the performance of government //The efficiency of public administration. - 2013. - Vol. 34. - P. 275-283.

9. CAF Resource Centre of the European Institute of Public Administration, m. Maastricht. Available from: http://www. eipa.eu/en/pages/show/\&tid=69.

\section{References}

1. Homenko VM. [Research of modern mechanisms of state and social regulation in pharmacy]. Visnyk farmatsii. 2007;3(51): 38-42. Ukrainian.

2. Nemchenko AS. [Defining policy priorities of the pharmaceutical industry based on expert assessments]. Farmats zhurn. 2008;2: 3-8. Ukrainian.

3. Nemchenko AS. [The problems of the pharmaceutical industry: peer review of experts]. Farmatsevtychnyi chasopys. 2008;2(6): 11-13. Ukrainian.

4. [Recent regulation of the industry. Meeting of professional pharmaceutical association]. Ezhenedelnik Apteka. 2010;727(6): 10. Ukrainian.

5. Pashkov V. [Self-regulation of the pharmaceutical mar-

ket]. Ezhenedelnik Apteka. 2013;41(912). Ukrainian. 6. Bocherikova E. [Combining professional help efforts of Pharmacy in Ukraine]. Ezhenedelnik Apteka. 2016;40(1061). Ukrainian.

7. Susharina IV. [Scientific and methodological approaches to evaluating the effectiveness of NGOs in pharmacy]. Upravlinnia, ekonomika ta zabezpechennia yakosti v farmatsii. 2016;3: 6-74. Ukrainian.

8. Oliynyk D. [Modern methods of evaluating the performance of government]. The efficiency of public administration. 2013;34: 275-283.

9. CAF Resource Centre of the European Institute of Public Administration, m. Maastricht, Available from: http://www. eipa.eu/en/pages/show/\&tid=69.

Отримано 25.01.2017

ISSN 2312-0967. Фармацевтичний часопис. 2017. № 1 